\title{
Biochemical and Biotechnological Studies on Xylanase and $\beta$-xylosidase Enzymes Produced by Trichoderma viride Under Solid State Fermentation
}

\author{
Ayman A. Farrag ${ }^{1,2}$ (D), Mohammed H. EL-Haw ${ }^{3}$ iD \\ and Ahmad A.K Al-Bokhomy** \\ ${ }^{1}$ Microbiology Department Faculty of Science, Al-Azhar University, Egypt. \\ ${ }^{2} \mathrm{Al}$-Azhar Center for Fermentation Biotechnology and Applied Microbiology, Egypt. \\ ${ }^{3}$ Department of Botany and Microbiology, Faculty of Science, Al-Azhar University, Cairo, Egypt. \\ ${ }^{4} \mathrm{Al}$-Azhar University, Tanta, Egypt.
}

\begin{abstract}
The current study concerns with enhancement of xylanase and $\beta$-xylosidase activities from lignocellulosic materials by soil derived fungi Trichoderma viride under solid state fermentation (SSF). Xylanase and $\beta$-xylosidase activities were found to affected by variety of factors. In this study, some agricultural wastes were selected and used as sources for carbon. Sugar beet pulp (SBP) was at the forefront of these types. Also, various sources for nitrogen were selected to determine the best one. Yeast extract was the best organic source. Maximum xylanase activity took place by using inoculum size $1.8 \times 10^{5}$ spores $/ \mathrm{ml}$ at $30^{\circ} \mathrm{C}$ when the $\mathrm{pH}$ was 5.5 for eight days of incubation with the addition of $0.1 \%$ of Tween 40. Moreover, spores of Trichoderma viride were irradiated with gamma-rays. The maximum activity was observed upon using $\mathbf{0 . 7}$ kilo-gray (kGy). Furthermore, mixed cultures of Trichoderma viride and Penicillium janthenellum (wt / wt) were enhanced xylanase degrading capability. From another standpoint, ammonium sulphate and gel filtration chromatography were the best methods for xylanase purification. Characterizations of the purified enzyme were also selected and studied. It was found that, $\beta$-xylosidase enzyme exhibited its maximum activity and stability when the $\mathrm{pH}$ was 6 at $40^{\circ} \mathrm{C}$ by the addition of $\mathrm{CaCl}_{2}$ metal ion. On the other hand, total protein contents and volatile constituents of Trichoderma viride and Penicillium janthenellum were separated and investigated using high performance liquid chromatography (HPLC) and gas chromatography/mass spectrometry (GC/MS) techniques. It was found that, total protein contents for Trichoderma viride and Penicillium janthenellum were represented by fifteen and sixteen amino acids respectively. Also,29 compounds of the total volatile compounds for both Trichoderma viride and Penicillium janthenellum were identified. On the practical and applied field, crude enzyme was a good analyzer for agricultural residues as well showed antifungal and antibacterial effects.
\end{abstract}

Keywords: Antibacterial, Antifungal, Biochemical, Biotechnological, $\beta$-xylosidase, Gamma-rays, GC / MS, HPLC, Trichoderma viride, Xylanase

*Correspondence: ahmadalbokhomy@gmail.com

(Received: September 27, 2020; accepted: January 11, 2021)

Citation: Farrag AA, EL-Haw MH, Al-Bokhomy AA.K. Biochemical and Biotechnological Studies on Xylanase and $\beta$-xylosidase Enzymes Produced by Trichoderma viride Under Solid State Fermentation. J Pure Appl Microbiol. 2021;15(1):138-154. doi:10.22207/JPAM.15.1.09

(C) The Author(s) 2021. Open Access. This article is distributed under the terms of the Creative Commons Attribution 4.0 International License which permits unrestricted use, sharing, distribution, and reproduction in any medium, provided you give appropriate credit to the original author(s) and the source, provide a link to the Creative Commons license, and indicate if changes were made. 


\section{INTRODUCTION}

Biotechnology is a branch of sciences that concerned with the commercial use of living organisms and /or their products. This technology covers a wide range of areas including medicine, environment, agriculture, industry and pharmacy to develop useful and promising products ${ }^{37}$. Medical biotechnology is concerned with the use of biological compounds in the field of human health and disease diagnosis at initial stage of the disease. Environmental biotechnology is defined as the development of biological compounds to treat environmental pollutants and convert them into harmless compounds ${ }^{32}$. Agricultural biotechnology includes some agricultural crops which can be used to produce petroleum products via chemical processes such as jatropha plant in the field of biodiesel production. Sugar also fermented into acid, as it can be used for various industrial purposes ${ }^{24,30,34}$. Agriculture wastes are one of the biggest problems in our world. If this problem is not solved, it will lead to environmental pollution. Industrial biotechnology includes the use of living organisms and/or their products to improve efficiency and reduce environmental impacts from industrial processes such as paper, textile, pulp and chemical industries ${ }^{15}$. This technique involves developing enzymes as biocatalysts to synthesize chemical compounds. Lignocellulosic biomass have a great potential to be used in the industrial processes, particularly in the field of enzymes production ${ }^{31}$. Xylane is the main part of plant polysaccharides ${ }^{18}$. It is a complex polysaccharide that made of xyloseresidue backbone each subunit linked to each other by a $\beta-1,4$-glycosidic bond ${ }^{27}$. Xylanases are groups of enzymes complexes that break down xylane. These enzymes are specific to substrates which cleave chemical bonds of different nature ${ }^{6}$. $\beta$-xylosidases are the most extensively studied components of this system. This enzymatic system was efficient for biodegradation of agricultural wastes and will ultimately provide means to a 'greener technology's. The degradation of plant cell walls requires a large number of enzymes with different specificity ${ }^{12}$. Lignin is an undesirable component in the pulp and paper industry which removed by chemical treatments process and this called enzymatic hydrolysis of lignocellulose ${ }^{35}$. Fungi are known to produce a vast range of secondary metabolites such as enzymes, vitamins, antibiotics, polysaccharides and other organic acids which equivalent to that chemically synthesized ${ }^{10}$. The production of secondary metabolites by Trichoderma and Penicillium shows great variety and application potential in this field pharmaceutical and human health applications. Fungi are capable of producing several important secondary metabolites which are used as antifungal and antibacterial agents ${ }^{23}$. Fungi are capable of synthesize the bioactive metabolites from few precursors using unique biochemical path-way ${ }^{7}$. Trichoderma viride and Penicillium janthenellum recorded antifungal and antibacterial effects against Candida sp. and E. coli respectively2.

\section{Aims and Highlights of This Study}

The aim of this work is to use Trichoderma viride and Penicillium janthenellum for xylanase production during growth on solid substrates and describes approaches for biotechnological applications.

We carried out this study in the following areas:

1. Quantitative survey for xylanase and $\beta$ xylosidase activities.

2. Optimization of the fermentation parameters affecting enzymes production.

3. Enzyme purification by different methods.

4. Characterizations of the purified enzyme produced.

5. HPLC and GC/MS analysis of the crude extract and the volatile constituent.

6. Some agricultural wastes treatment and pharmaceutical applications.

\section{MATERIALS AND METHODS}

List of chemicals and reagents used

1. 4-nitro phenyl $\beta$-D-xylopyranoside

2. Acetone

3. Ammonium hydroxide

4. Ammonium sulfate

5. Boric acid

6. Cobalt (II) chloride pentahydrate

7. Copper (II) sulfate pentahydrate

8. Ethanol

9. Ferrous sulfate heptahydrate

10. lodine-potassium iodide

11. Magnesium sulfate

12. Magnesium sulfate heptahydrate

13. Manganese (II) chloride heptahydrate 


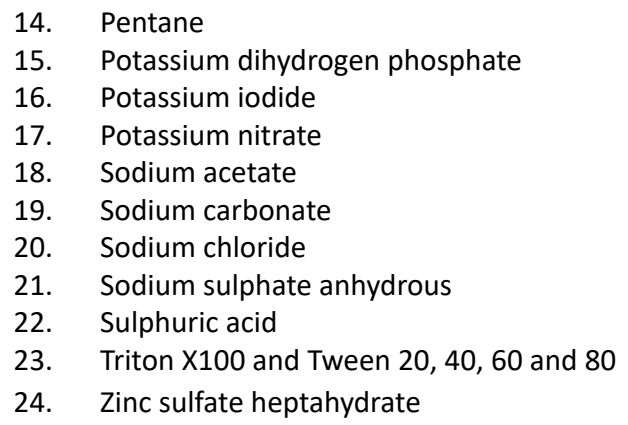

\section{Strains selection and media used}

Trichoderma viride (RCMB) 017002 and Penicillium janthenellum (RCMB) 001033 [1] were selected to produce xylanase and $\beta$-xylosidase under solid state fermentation. These strains were obtained from Al Azhar University, The Regional Center for Mycology and Biotechnology, Cairo, Egypt. Media used for screening must contain micronutrient elements such as carbone and nitrogen sources in addition to other metals (Table 1).

\section{Xylanase production and estimation}

Trichoderma viride and Penicillium janthenellum were grown on modified agar media followed by observing zones around colonies. After the colonies reached around $3 \mathrm{~mm}$, iodinepotassium iodide solution (1.0 g iodine, $5.0 \mathrm{~g}$ potassium iodide, and $330 \mathrm{ml}$ distilled water) was added to detect clearance zones. The fermentation was done in $125 \mathrm{ml}$ flasks contained $5 \mathrm{~g}$ of lignocellulosic materials at $30^{\circ} \mathrm{C}$ when $\mathrm{pH}$ was $5^{8}$. A nutrient solution used for keeping the moisture level at $70 \%$ (Table 2).

After the experimental time run out, 50 $\mathrm{ml}$ of distilled water was added to the fermentation

Table 1. Media used for xylanase production ${ }^{25}$ : Add to $100 \mathrm{ml}$ of distilled water the following elements

\begin{tabular}{ll} 
Carbone source & $0.1 \mathrm{~g}$ of sugar beet pulp \\
\hline $\mathrm{MgSO}_{4} .7 \mathrm{H} 2 \mathrm{O}$ & $0.5 \mathrm{~g}$ \\
$\mathrm{KNO}_{3}$ & $1.0 \mathrm{~g}$ \\
$\mathrm{NaCl}_{\text {Trace element }}$ & $0.5 \mathrm{~g}$ \\
solution & $0.1 \mathrm{ml}$ (Add to $100 \mathrm{ml}$ of distilled \\
& water: $(0.5 \mathrm{~g}) \mathrm{FeSO}_{4} .7 \mathrm{H}_{2} \mathrm{O},(2.0 \mathrm{~g})$ \\
& $\mathrm{ZnSO}_{4} .7 \mathrm{H}_{2} \mathrm{O},(0.15 \mathrm{~g}) \mathrm{CuSO}_{4} .5 \mathrm{H}_{2} \mathrm{O}$, \\
& $(0.5 \mathrm{~g}) \mathrm{MnCl}_{2} .7 \mathrm{H}_{2} \mathrm{O},(0.15 \mathrm{~g}) \mathrm{CoCl}_{2}$. \\
& $5 \mathrm{H}_{2} \mathrm{O}$ and $\left.(1.0 \mathrm{~g}) \mathrm{H}_{3} \mathrm{BO}_{3}\right)$.
\end{tabular}

flask and the mixture was stirred at $100 \mathrm{rpm}$ for $1 \mathrm{~h}$. Solid phase was removed by the vacuum filtration and the liquid phase was centrifuged at $10.000 \mathrm{xg}$. The supernatant was used as crude enzyme solution. In this study, $0.2 \mathrm{ml}$ of the crude enzyme solution was added to flask contained 4 $\mathrm{ml}$ of $0.5 \%(\mathrm{w} / \mathrm{v})$ substrates dissolved in $200 \mathrm{mM}$ citrate solution with $\mathrm{pH} 5.5$ at $25^{\circ} \mathrm{C}$. For enzyme estimation, optical density was measured at zero time and after $1 \mathrm{~min}$ by used spectrophotometer (Hitachi model U-2000 with electronic temperature control unit) at $235 \mathrm{~nm}$.

\section{Xylanase optimization and purification}

Xylanase production was induced by various factors such as carbon sources, nitrogen sources, inoculum sizes, incubation periods, $\mathrm{pH}$ values, incubation temperatures, surfactants, gamma irradiation doses and mixed cultures of Trichoderma viride/Penicillium janthenellum. In this study, centrifugation and gel filtration chromatography were selected for xylanase purification. In centrifugation method, ammonium sulfate was added to $500 \mathrm{ml}$ of cultural filtrate to reached to $60 \%$ saturation, and leave for 60 min at $4^{\circ} \mathrm{C}$, then centrifuged for $20 \mathrm{~min}$ at 9000 $\mathrm{rpm}$ to separate the pellets. Ammonium sulfate was added again to supernatant to bring to $70 \%$ saturation and leave overnight, then centrifuged at $9000 \mathrm{rpm}$ for $20 \mathrm{~min}$, then $50 \mathrm{ml}$ of sodium acetate solution was added to dissolve the active fraction with maintained the $\mathrm{pH}$ to 6 and dialyzed against the same buffer ${ }^{1}$. In gel filtration chromatography method, Sephadex G-100 column was loaded with dialyzed enzyme and eluted with sodium acetate buffer at pH 5.9 and flow rate $20 \mathrm{ml} / \mathrm{h}$. Total 30 fractions of $5 \mathrm{ml}$ were subsequently collected and its protein content was measured at optical density 280 using spectrophotometer (UV-VIS 1601 Shimadzu, Japan). The fractions that showed

Table 2. Nutrient solution composition: Add to $100 \mathrm{ml}$ of distilled water the following elements

\begin{tabular}{ll}
\hline$\left(\mathrm{NH}_{4}\right)_{2} \mathrm{SO}_{4}$ & $0.35 \mathrm{~g}$ \\
$\mathrm{MgSO}_{4} \cdot 7 \mathrm{H}_{2} \mathrm{O}$ & $0.05 \mathrm{~g}$ \\
$\mathrm{KH}_{2} \mathrm{PO}_{4}$ & $0.30 \mathrm{~g}$ \\
$\mathrm{Tw}_{4} 80$ & $1.0 \mathrm{~g}$ \\
Micronutrient & $0.1 \mathrm{ml}$ (add to $100 \mathrm{ml}$ of distilled \\
solution & water: $(0.05 \mathrm{~g})\left(\mathrm{NH}_{4}\right) \mathrm{SO}_{4}(0.05 \mathrm{~g})$ \\
& $\mathrm{MgSO}_{4}$ and $\left.(0.05 \mathrm{~g}) \mathrm{KH}_{2} \mathrm{PO}_{4}\right)$. \\
\hline
\end{tabular}


higher enzymatic activity were pulled together for characterization ${ }^{29}$.

\section{$\beta$-xylosidase activity measurement}

Sodium carbonate solution was added to 4-nitro phenyl $\beta$-D-xylopyranoside as a substrate followed by addition of enzymatic extract with adjust the $\mathrm{pH}$ to 5 at $60^{\circ} \mathrm{C}$ for $10 \mathrm{~min}^{8}$. The unit of enzyme activity $(U)$ was defined as the amount of enzyme required to release $1 \mu \mathrm{mol}$ of reducing sugar per minute ${ }^{19}$.

\section{Characterization of $\beta$-xylosidase enzyme}

In this study, the activity and stability of $\beta$-xylosidase enzyme were induced by various factors such as $\mathrm{pH}$ values, temperatures, and metal ions within concentration of $10 \mathrm{mM}^{26}$.

Total protein content and investigation of the volatile constituents

Fungal mycelia were extracted with $70 \%$ ethanol. Separation of proteins were done according to Bellomonte et al. $1987^{4}$. In this method, $2.5 \mathrm{~g}$ of extract was dissolved in mixture of $(10 \mathrm{ml}$ distilled water, $23 \mathrm{ml}$ ethanol and $2.5 \mathrm{ml}$ sulphuric acid) and leave for $20 \mathrm{~min}$ at $27^{\circ} \mathrm{C}$. Then, $25 \mathrm{ml}$ of distilled water and $125 \mathrm{ml}$ ethanol were added again. Ammonium hydroxide was added to adjust the $\mathrm{pH}$ to 3 and the mixture was filtrated. Acetone was added till precipitate was formed and centrifuged at $4000 \mathrm{rpm}$, then collected, dried and weighed. Then, HPLC analysis was detected. On the other hand, $25 \mathrm{~g}$ of fresh mycelia was distilled with pentane as organic solvent. The pentane layer was collected, dried over sodium sulphate anhydrous and stored at $4^{\circ} \mathrm{C}$ for $\mathrm{GC} / \mathrm{MS}$ analysis. Then, investigation of the volatile constituents was also detected.

\section{Xylanase applications}

Xylanase was used for treatment of some agricultural residues such as wheat, rice straw and sugar cane bagasse ${ }^{21}$. In this study, 50 $\mathrm{ml}$ of crude enzyme was mixed with each residue in shaking flasks with $120 \mathrm{rpm}$ for 24 and $48 \mathrm{~h}$ at $50^{\circ} \mathrm{C}$ and $\mathrm{pH}$ 7. The supernatant used to determine the reducing sugar. Also, crude extraction from fresh fungi Trichoderma viride and Penicillium janthenellum were evaluated as antimicrobial agents (antibacterial and antifungal) using antibiotic assay method. In this method, 50, 100, 150, and $200 \mu \mathrm{g} / \mathrm{disc}$ crude extract of Penicillium janthenellum and Trichoderma viride were tested against Candida sp. and E. coli using Sabouraud dextrose and nutrient agar media respectively. Fungal plates were incubated under aseptic conditions for $72 \mathrm{~h}$ at $28^{\circ} \mathrm{C}$ while, bacterial plates were incubated for $24 \mathrm{~h}$ at $30^{\circ} \mathrm{C}$. The diameter of inhibition zone $(\mathrm{mm})$ for each pathogen was determined exactly and then, the mean of the triplicates was calculated.

\section{RESULTS}

Screening to choose the most potent fungal strain Trichoderma viride and Penicillium janthenellum were compared for xylanase production because of their higher ability to produce the enzyme. They showed xylanase activities represented by 330.3 and $220.5 \mathrm{U} /$ gds for Trichoderma viride and Penicillium janthenellum respectively (Table 3 ).

\section{Xylanase optimization produced by Trichoderma} viride

In this study, we focused on Trichoderma viride for xylanase production. The organism ingested nutrients to live and produces secondary metabolites. Secondary metabolites were found to affect by various factors. Carbon source played an important role in the production of xylanase. To reduce the cost of enzyme production, an inexpensive lignocellulosic substrate should be preferred. The results showed that, sugar beet pulp (SBP) was the best source for carbon that exhibited the maximum xylanase activity while, other carbon sources gave lower activities. Wheat bran and (SBP + broad bean) exhibited un-noticeable change

Table 3. Screening of the most potent fungal xylanase producers

\begin{tabular}{lccc}
\hline Enzyme & \multicolumn{2}{c}{ Strains and enzymatic activities (U / gds) } \\
\cline { 2 - 4 } & $\begin{array}{l}\text { Penicillium janthenellum } \\
\text { (RCMB) 001033[1] }\end{array}$ & $\begin{array}{c}\text { Trichoderma viride } \\
\text { (RCMB) 017002 }\end{array}$ & \\
\hline Xylanase & $220.5 \pm 0.5$ & $330.3 \pm 0.06$ & www.microbiologyjournal.org
\end{tabular}


of enzymatic activity which represented by 130 and $131.5 \mathrm{U} / \mathrm{gds}$ respectively. There were slightly noticeable differences between (SBP + wheat bran) and (SBP + banana) which gave enzymatic activities represented by 220 , and $224 \mathrm{U} / \mathrm{gds}$ respectively

(Fig. 1). Nitrogen source also was optimized

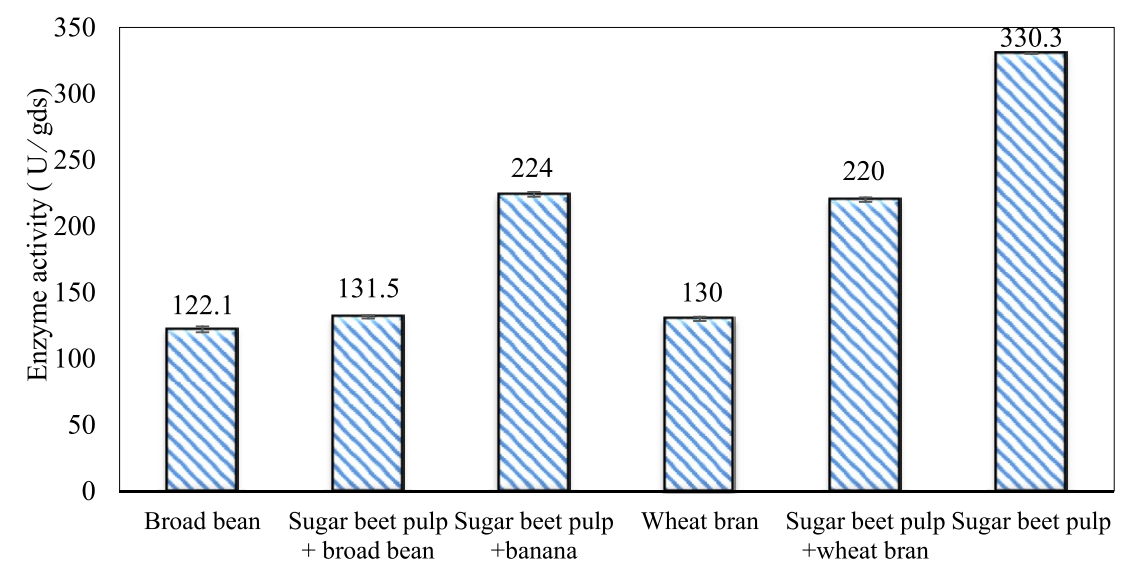

Different carbon sources

Fig. 1. Effect of different carbon sources on xylanase activity

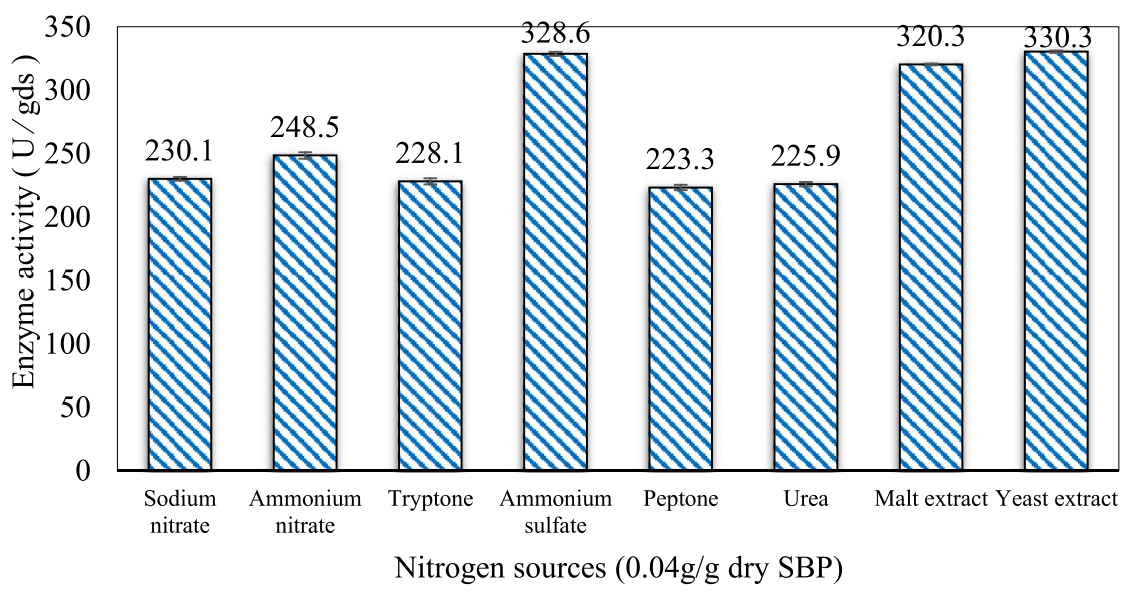

Fig. 2. Effect of different nitrogen sources on xylanase activity

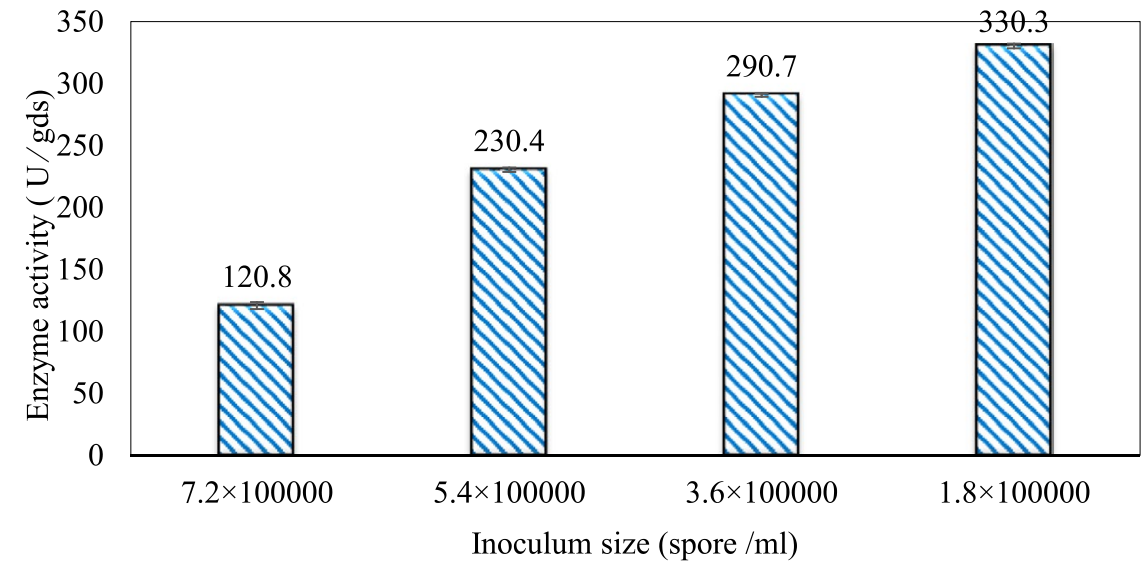

Fig. 3. Effect of different inoculum sizes on xylanase activity 
for maximum xylanase production under SSF. It was found that, the most potent nitrogen sources were yeast extract as organic source and ammonium sulfate as inorganic one which the activities represented by 330.3 and $328.6 \mathrm{U} / \mathrm{gds}$ respectively. Malt extract was the third nitrogen source that gave noticeable change of enzymatic activity after yeast extract and ammonium sulphate. Other nitrogen sources including organic and inorganic gave lower xylanase activity (Fig.

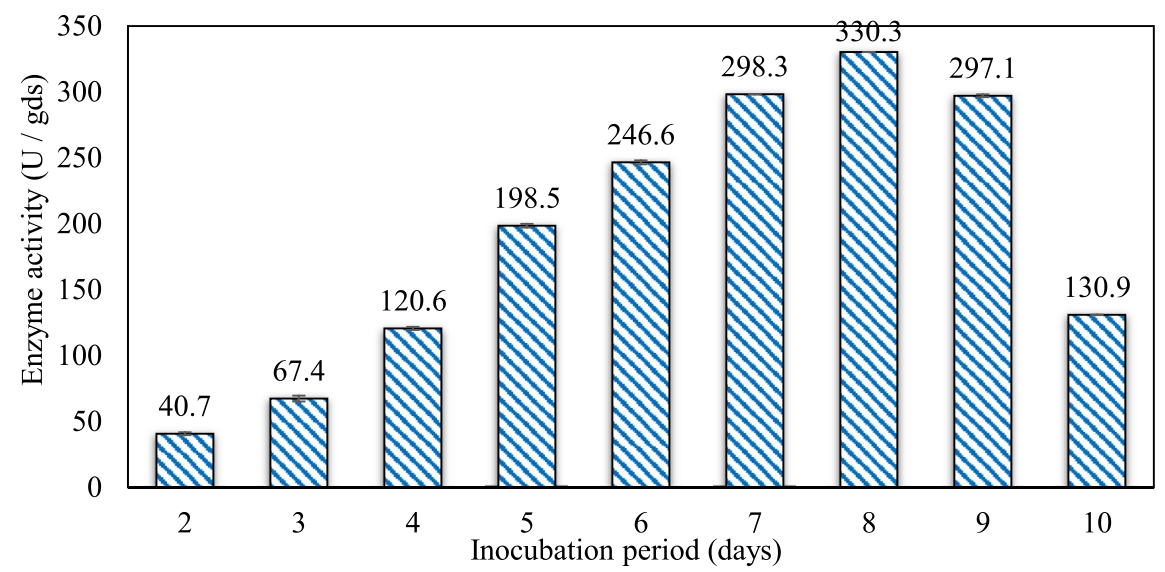

Fig. 4. Effect of different incubation periods on xylanase activity

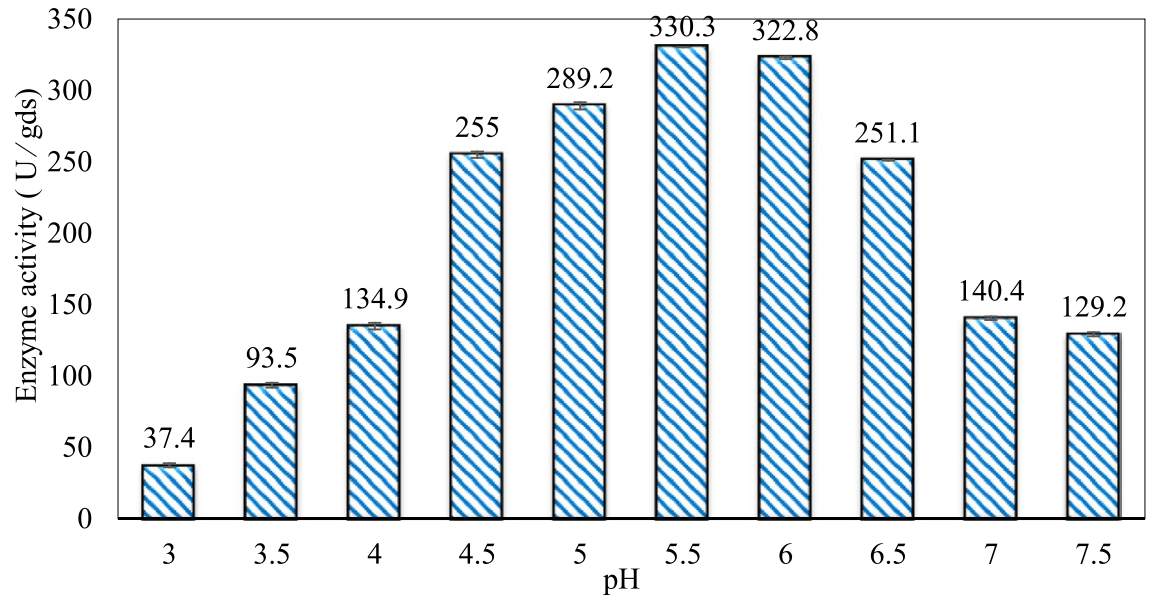

Fig. 5. Efect of different $\mathrm{pH}$ values on xylanase activity

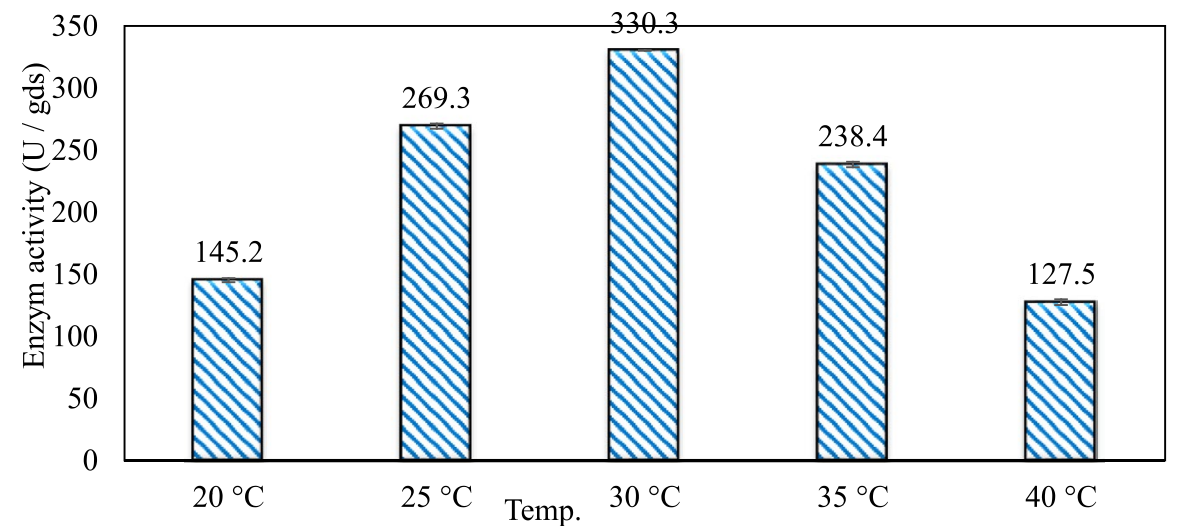

Fig. 6. Effect of different incubation temperatutres on xylanase activity 
2 ). The maximum xylanase activity produced at inoculum size $1.8 \times 10^{5} \mathrm{spores} / \mathrm{ml}$. As inoculum size increased, xylanase activity decreased (Fig. 3). The period of incubation was also optimized to find out the time period for maximum xylanase production. Trichoderma viride started xylanase activity from the second day of incubation period with slightly enzymatic activity. The enzyme activity

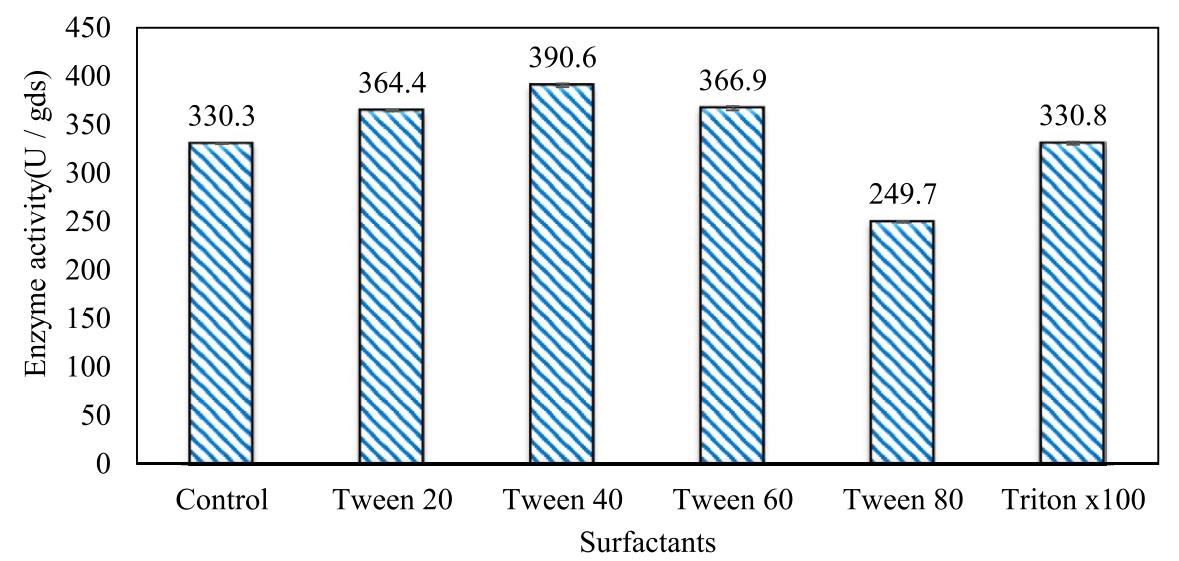

Fig. 7. Effect of different surfactants on xylanase activite

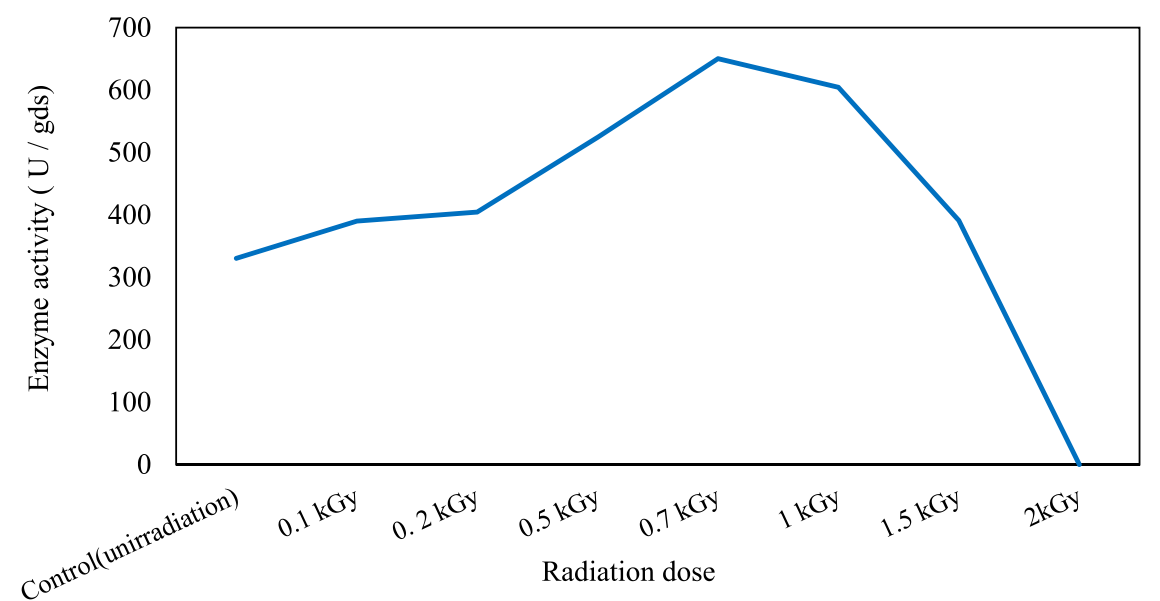

Fig. 8. Effect of different gamma-irradition doses on xylanase activity

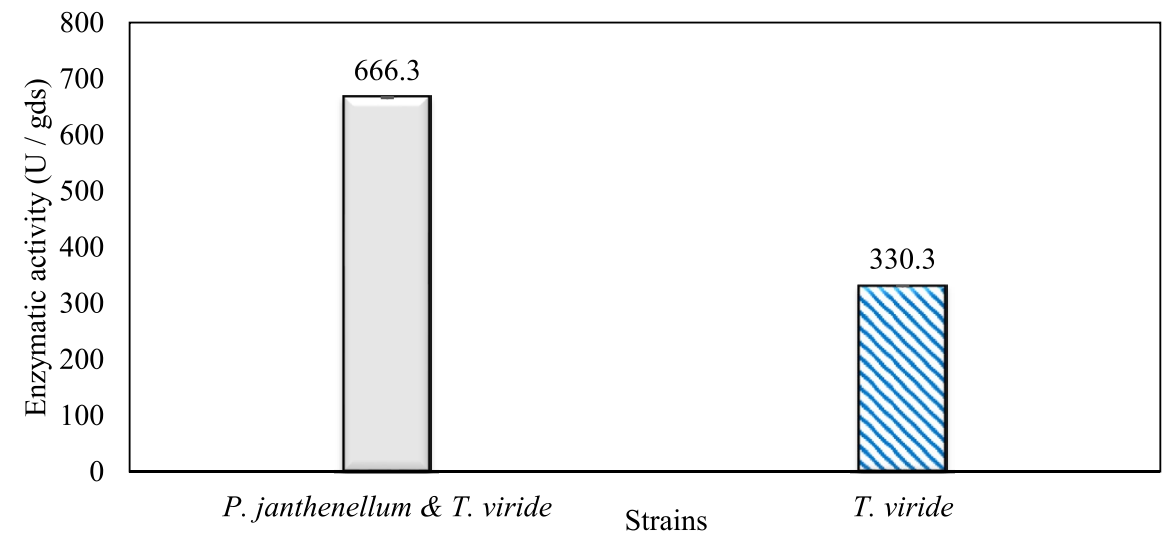

Fig. 9. Effect of mixed cultures on xylanase activity 
increased as the incubation period increased and reached its maximum activity on the eighth day of the incubation period, then began to decrease significantly as the incubation period increase. However, xylanase activity still moderately high even on the ninth day of the incubation period (Fig. 4). The $\mathrm{pH}$ values of the culture medium also affect the production of enzyme. Several fungi are able to produce xylanase in acidic medium. Trichoderma viride was able to produce xylanase at all tested $\mathrm{pH}$ values. It was shown that, at low $\mathrm{pH}$ ranges $(3-4)$, the activity was very low, then began to increase gradually until reached its maximum activity at $\mathrm{pH}$ ranges $(5-6)$. The maximum activity was achieved at $\mathrm{pH} 5.5$, then the activity started to decrease at $\mathrm{pH}$ ranges (6.5 - 7.5) (Fig. 5). Temperature is one of the most essential parameters that found to affect the production of xylanase under SSF. Trichoderma viride started xylanase activity at $20^{\circ} \mathrm{C}$ and reached its maximum rate at $30^{\circ} \mathrm{C}$, then the activity started to decrease as the incubation temperature increased. Above

Table 4. Summary of the optimum conditions for the xylanase production

\begin{tabular}{ll}
\hline Physiological factors & Results \\
\hline Incubation period (days) & 8 \\
Temperature $\left({ }^{\circ} \mathrm{C}\right.$ ) & 30 \\
pH value & 5.5 \\
Carbon source & Sugar beet pulp \\
Nitrogen source & Yeast extract \\
Inoculum size (spores / ml) & $1.8 \times 10^{5}$ \\
Surfactants & Tween 40 \\
Radiation $(\mathrm{kGy})$ & 0.7
\end{tabular}

the optimum temperature $\left(30^{\circ} \mathrm{C}\right)$, the enzyme denatured and thus the production decreased (Fig. 6). Surfactants were found to make a dispersing effect on the media and result in enhanced the aeration and increase in the enzyme secretion. The highest xylanase activity was observed upon addition of $0.1 \%$ of Tween 40 . Tweens 20 and 60 caused slightly increase on activities as compared to Tween 40, while no effect occurred upon using triton X-100 (Fig. 7). Spores of Trichoderma viride were irradiated with slightly doses of gamma-rays. The maximum xylanase activity was achieved upon using $0.7 \mathrm{kGy}$ of gamma irradiation dose then, the activity decreased as gamma irradiation doses increased until reached to $2 \mathrm{kGy}$ of gamma irradiation doses, the enzyme activity faded (Fig. 8). Also, mixed cultures of Trichoderma viride and Penicillium janthenellum were found to increase xylanase degrading capability by about $101.75 \%$ higher than Trichoderma viride only and $202.2 \%$ higher than Penicillium janthenellum only (Fig. 9). Data in (Table 4) showed summarize of the optimum conditions used for the xylanase production.

\section{Xylanase purification and $\beta$-xylosidase characterization}

Xylanase purification was done by the centrifugation followed by ammonium sulphate. When cultural filtrate was saturated with ammonium sulphate up to $60 \%$, the enzyme activity decreased to $6.03 \mathrm{U} / \mathrm{ml}$, while supernatant was saturated again up to $75 \%$, the enzyme activity raised to $13.47 \mathrm{U} / \mathrm{ml}$. While, enzyme without ammonium sulphate exhibited activity determined

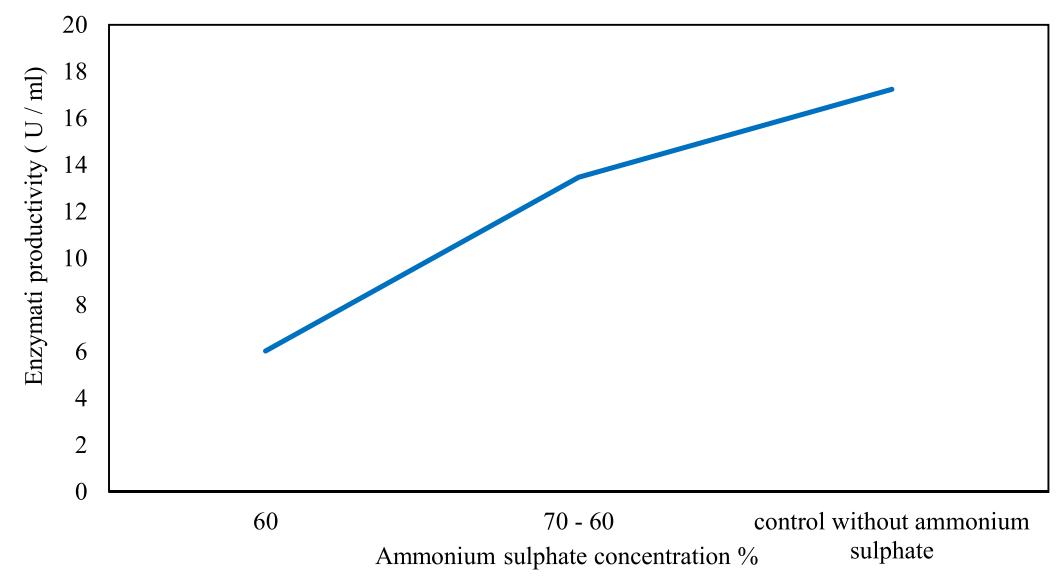

Fig. 10. Partial purification of xylanase 
by $17.24 \mathrm{U} / \mathrm{ml}$ (Fig. 10). From the results, $\beta$ xylosidase exhibited its maximum activity and stability when the $\mathrm{pH}$ was 6 at $40^{\circ} \mathrm{C}$ within addition of $\mathrm{CaCl}_{2}$ (Fig. 11,12,13,14 and 15).
Total protein content and investigation of the volatile constituents

Trichoderma viride exhibited protein content represented by $12 \%(\mathrm{wt} / \mathrm{wt})$, while

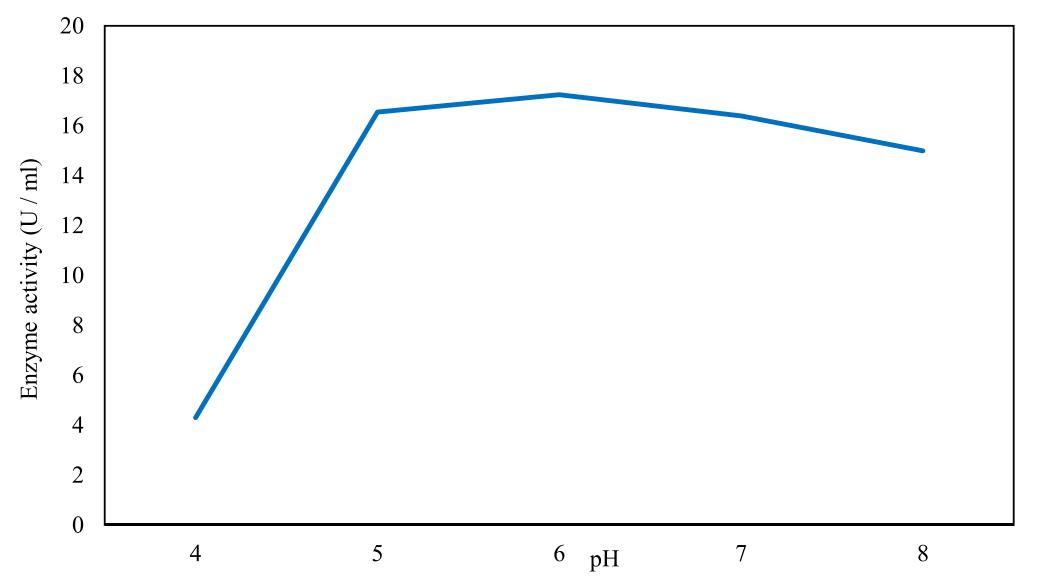

Fig. 11. Effect of different $\mathrm{pH}$ values on activity of the purified $\beta$-xylosidase

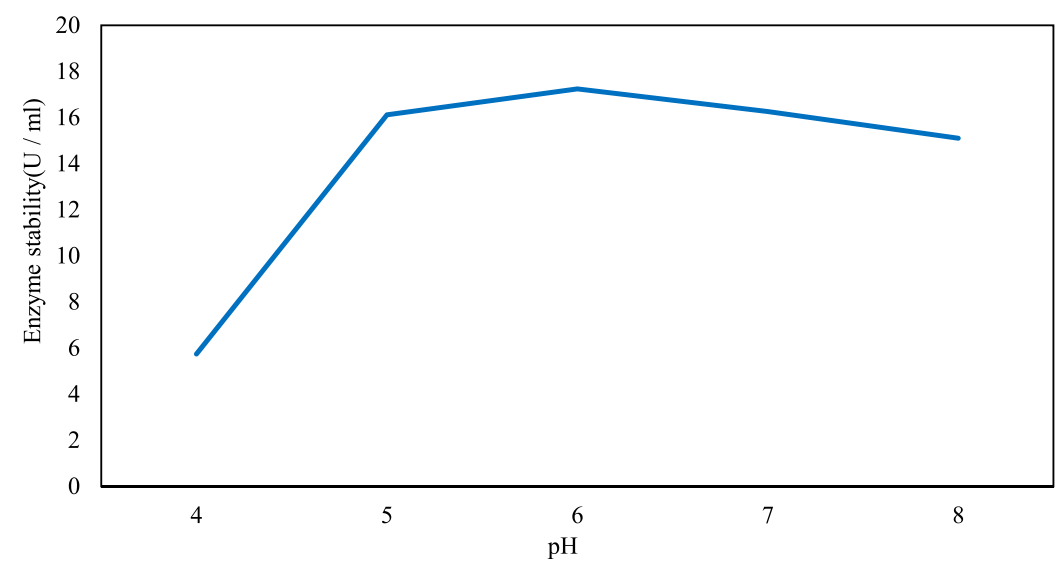

Fig. 12. Effect of different $\mathrm{pH}$ values on stability of the purified $\beta$-xylosidase

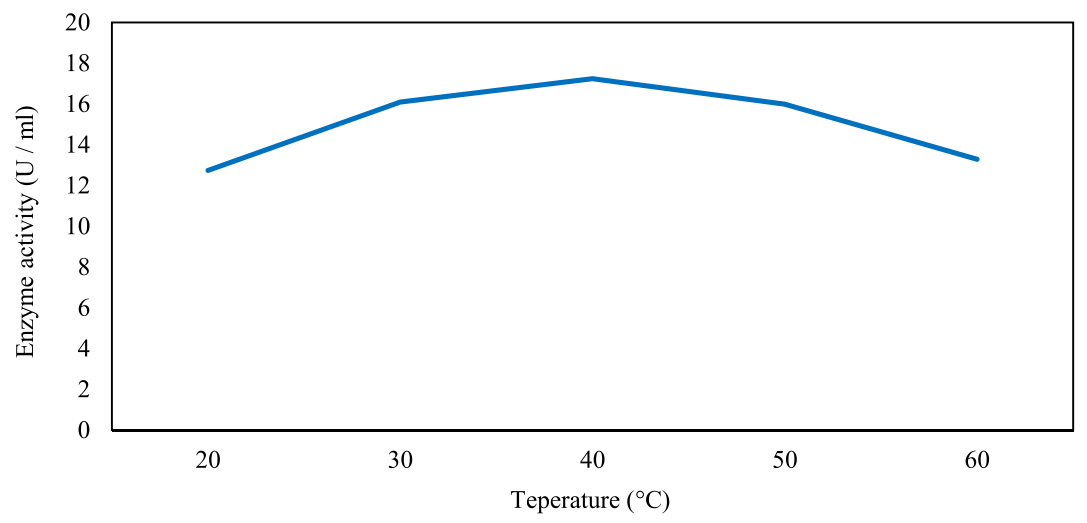

Fig. 13. Effect of different temperatures on activity of the purified $\beta$ - xylosidase 


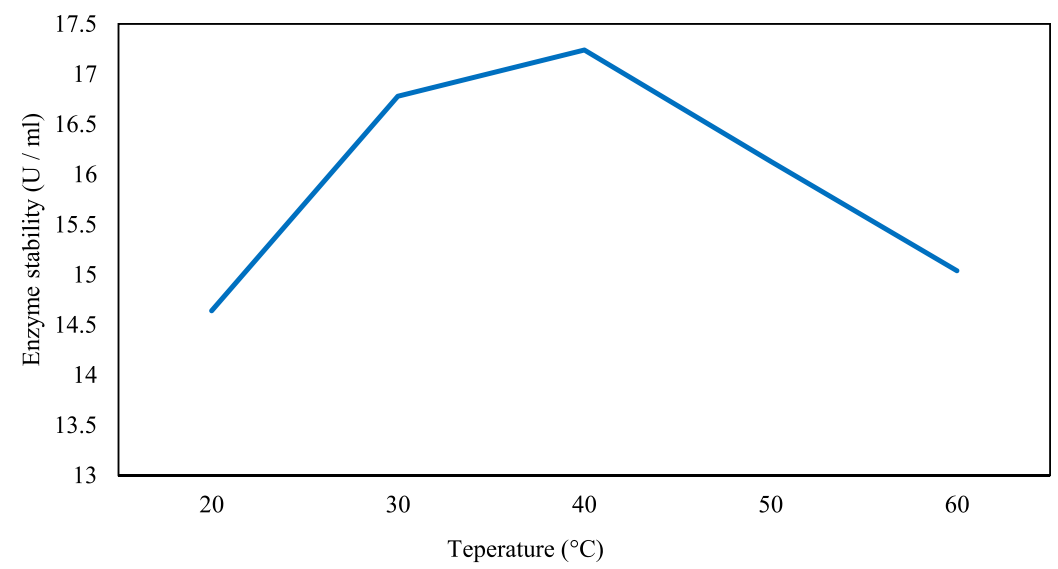

Fig. 14. Effect of different temperatures on stability of the purified $\beta$-xylosidase

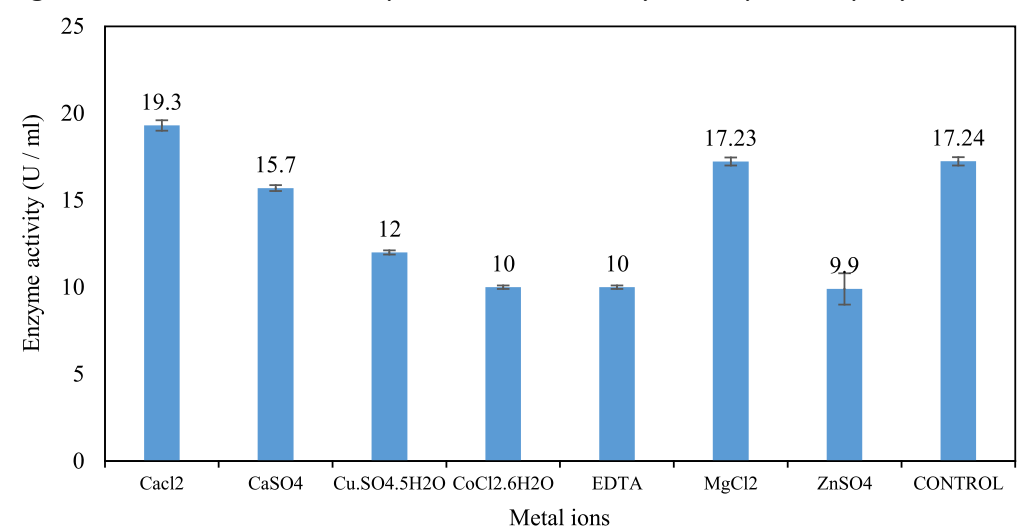

Fig. 15. Effect of different metal ions on activity of the purified $\beta$-xylosidase

Table 5. Total protein content of $T$. viride and $P$. janthenellum

\begin{tabular}{|c|c|c|c|c|}
\hline \multirow[t]{2}{*}{ Amino acids } & \multicolumn{2}{|c|}{ Penicillium janthenellum } & \multicolumn{2}{|c|}{ Trichoderma viride } \\
\hline & Time (min) & Amino acids (\%) & Time (min) & Amino acids (\%) \\
\hline Threonine & 14.08 & 2.98 & 12.48 & 2.35 \\
\hline Valine & 29.08 & 3.14 & 30.13 & 4.87 \\
\hline Methionine & 33.87 & 10.88 & 32.76 & 10.89 \\
\hline Isoleucine & 36.47 & 2.66 & 34.51 & 3.87 \\
\hline Leucine & 38.18 & 3.16 & 36.29 & 2.27 \\
\hline Phenylalanine & 42.95 & 5.52 & 41.11 & 6.91 \\
\hline Lysine & 52.17 & 9.01 & 49.48 & 9.23 \\
\hline Histidine & 54.04 & 4.14 & 0 & 0 \\
\hline \multicolumn{2}{|c|}{ Total essential amino acids } & $41.49 \%$ & & $40.39 \%$ \\
\hline Aspartic acid & 13.40 & 8.07 & 8.13 & 8.84 \\
\hline Serine & 16.90 & 4.20 & 11.83 & 6.25 \\
\hline Glutamic acid & 18.45 & 6.88 & 13.52 & 13.93 \\
\hline Glycine & 24.45 & 7.14 & 20.52 & 3.79 \\
\hline Proline & 25.95 & 2.18 & 22.22 & 5.28 \\
\hline Alanine & 27.85 & 10.44 & 23.92 & 8.58 \\
\hline Tyrosine & 42.84 & 11.15 & 42.92 & 6.97 \\
\hline Arginine & 65.29 & 8.45 & 61.22 & 5.97 \\
\hline \multicolumn{2}{|c|}{ Total nonessential amino acid } & $58.51 \%$ & \multicolumn{2}{|c|}{$59.61 \%$} \\
\hline \multicolumn{3}{|c|}{ Total identified amino acids } & \multicolumn{2}{|c|}{$100 \%$} \\
\hline
\end{tabular}


Table 6. GC / MS analysis of the volatile constituents from P. janthenellum and T. viride mycelia

\begin{tabular}{|c|c|c|c|c|c|c|c|}
\hline $\begin{array}{l}\text { Peak } \\
\text { No. }\end{array}$ & Strain & $\begin{array}{l}\text { Time } \\
\text { (min) }\end{array}$ & $\begin{array}{l}\text { Boiling } \\
\text { Point }\left({ }^{\circ} \mathrm{C}\right)\end{array}$ & $\begin{array}{l}\text { Mol. wt. } \\
\text { (g / mol) }\end{array}$ & $\begin{array}{l}\text { Mol. } \\
\text { Formula }\end{array}$ & Compound & $\%$ \\
\hline \multirow[t]{2}{*}{1} & P. janthenellum & 2.59 & 129 & 100.16 & $\mathrm{C}_{6} \mathrm{H}_{12} \mathrm{O}$ & Hexanal & 4.66 \\
\hline & T. viride & 3.48 & 57 & 128 & $\mathrm{C}_{8}^{6} \mathrm{H}_{16} \mathrm{O}$ & Cyclooctanol & 6.98 \\
\hline \multirow[t]{2}{*}{2} & P. janthenellum & 3.45 & 230.5 & 134.17 & $\mathrm{C}_{6} \mathrm{H}_{14} \mathrm{O}_{3}$ & Dipropylene glycol & 3.01 \\
\hline & T. viride & 4.19 & 41 & 130 & $\mathrm{C}_{6} \mathrm{H}_{10} \mathrm{O}_{3}$ & $\begin{array}{l}\text { 6,8-Dioxabicyclo } \\
\text { octan-4-ol }\end{array}$ & 2.85 \\
\hline \multirow[t]{2}{*}{3} & P. janthenellum & 5.52 & 218 & 134.18 & $\mathrm{C}^{9} \mathrm{H}_{10} \mathrm{O}$ & Propiophenone & 4.06 \\
\hline & T. viride & 4.52 & 218 & 134.18 & $\mathrm{C}_{9} \mathrm{H}_{10} \mathrm{O}$ & Propiophenone & 3.96 \\
\hline \multirow[t]{2}{*}{4} & P. janthenellum & 6.35 & 159 & 136.24 & $\mathrm{C}_{10}^{9} \mathrm{H}$ & Limonene & 2.23 \\
\hline & T. viride & 7.12 & 173 & 134.22 & $\mathrm{C}_{10} \mathrm{H}_{14}$ & Isobutylbenzene & 2.11 \\
\hline \multirow[t]{2}{*}{5} & P. janthenellum & 6.51 & 172 & 140.26 & $\mathrm{C}_{10} \mathrm{H}_{2} \mathrm{O}$ & Isobutyl cyclohexane & 1.75 \\
\hline & T. viride & 7.51 & 159 & 136.24 & $\mathrm{C}_{10} \mathrm{H}_{16}^{2}$ & Limonene & 2.79 \\
\hline \multirow[t]{2}{*}{6} & P. janthenellum & 7.12 & 195 & 142.24 & $\mathrm{C}_{9} \mathrm{H}_{18} \mathrm{O}$ & 2-nonanone & 2.12 \\
\hline & T. viride & 8.16 & 81 & 140 & $\mathrm{C}_{9} \mathrm{H}_{16} \mathrm{O}$ & $\begin{array}{l}\text { 6-Methyl- } \\
\text { bicyclooctan-7-ol }\end{array}$ & 1.96 \\
\hline \multirow[t]{2}{*}{7} & P. janthenellum & 7.54 & 235 & 148.2 & $\mathrm{C}_{10} \mathrm{H}_{12} \mathrm{O}$ & Isobutyrophenone & 2.82 \\
\hline & T. viride & 8.52 & 174.1 & 142.29 & $\mathrm{C}_{10} \mathrm{H}_{22}$ & n-Decane & 1.92 \\
\hline \multirow[t]{2}{*}{8} & P. janthenellum & 8.42 & 230.5 & 150.22 & $\mathrm{C}_{10} \mathrm{H}_{14} \mathrm{O}$ & Carvone & 2.34 \\
\hline & T. viride & 9.52 & 235 & 148.2 & $\mathrm{C}_{10} \mathrm{H}_{12} \mathrm{O}$ & Isobutyrophenone & 1.88 \\
\hline \multirow[t]{2}{*}{9} & P. janthenellum & 9.49 & 209 & 152.23 & $\mathrm{C}_{10} \mathrm{H}_{16} \mathrm{O}$ & Camphor & 1.98 \\
\hline & T. viride & 10.23 & 209 & 152.23 & $\mathrm{C}_{10} \mathrm{H}_{16} \mathrm{O}$ & Camphor & 1.73 \\
\hline \multirow[t]{2}{*}{10} & P. janthenellum & 13.57 & 258 & 164.24 & $\mathrm{C}_{11} \mathrm{H}_{16} \mathrm{O}$ & Jasmone & 2.13 \\
\hline & T. viride & 14.37 & 43 & 154 & $\mathrm{C}_{10}^{11} \mathrm{H}_{18} \mathrm{O}$ & 1,8-Cineole & 1.93 \\
\hline \multirow[t]{2}{*}{11} & P. janthenellum & 14.15 & 40 & 168.23 & $\mathrm{C}_{10} \mathrm{H}_{16} \mathrm{O}_{2}$ & Ascaridole & 2.07 \\
\hline & T. viride & 15.35 & 258 & 164.24 & $\mathrm{C}_{11} \mathrm{H}_{16} \mathrm{O}^{2}$ & Jasmone & 2.87 \\
\hline \multirow[t]{2}{*}{12} & P. janthenellum & 15.12 & 269.6 & 171.26 & $\mathrm{C}_{10} \mathrm{H}_{18} \mathrm{O}_{2}$ & Decanoate & 3.16 \\
\hline & T. viride & 17.12 & 40 & 168.23 & $\mathrm{H}_{16} \mathrm{O}_{2}^{2}$ & Ascaridole & 2.76 \\
\hline \multirow[t]{2}{*}{13} & P. janthenellum & 18.53 & 146 & 174.28 & $\mathrm{H}_{22} \mathrm{O}_{2}$ & di-tert-amyl peroxide & 2.18 \\
\hline & T. viride & 20.23 & 43 & 172 & $\mathrm{H}_{20} \mathrm{O}_{2}$ & $\begin{array}{l}\text { 1,2-Dihydro-8- } \\
\text { hydroxylinalool }\end{array}$ & 1.98 \\
\hline \multirow[t]{2}{*}{14} & P. janthenellum & 19.29 & 277 & 182.3 & $\mathrm{C}_{12} \mathrm{H}_{22} \mathrm{O}$ & Cyclododecanone & 1.32 \\
\hline & T. viride & 21.29 & 81 & 180 & $\mathrm{C}_{12} \mathrm{H}_{20} \mathrm{O}$ & 2,4-Dodecadienal & 1.23 \\
\hline \multirow[t]{2}{*}{15} & P. janthenellum & 20.31 & 259 & 186.34 & $\mathrm{C}_{12} \mathrm{H}_{26} \mathrm{O}$ & Dodecanol & 1.76 \\
\hline & T. viride & 22.37 & 184.32 & 184 & $\mathrm{C}_{12} \mathrm{H}_{24} \mathrm{O}$ & Dodecanal & 1.56 \\
\hline \multirow[t]{2}{*}{16} & P. janthenellum & 22.12 & 304 & 202.33 & ${ }_{26}^{24} \mathrm{O}_{2}$ & 1,12-Dodecanediol & 2.37 \\
\hline & T. viride & 24.17 & 55 & 200 & $\mathrm{C}_{12} \mathrm{I}$ & 1,2-Cyclododecanediol & 1.87 \\
\hline \multirow[t]{2}{*}{17} & P. janthenellum & 23.42 & 276 & 206.37 & $\mathrm{C}_{15} \mathrm{I}$ & Cedrane & 2.25 \\
\hline & T. viride & 25.42 & 121 & 204.35 & $\mathrm{C}_{15} \mathrm{H}_{24}$ & Isocaryophyllene & 3.45 \\
\hline \multirow[t]{2}{*}{18} & P. janthenellum & 24.46 & 330.6 & 220.35 & $\mathrm{C}_{15} \mathrm{H}_{24} \mathrm{O}^{24} \mathrm{O}$ & $\begin{array}{l}\text { Butylated hydroxyl } \\
\text { toluene }\end{array}$ & 2.91 \\
\hline & T. viride & 26.41 & 265.1 & 208.38 & $\mathrm{C}_{15} \mathrm{H}_{28}$ & Cyclopentadecene & 3.71 \\
\hline \multirow[t]{2}{*}{19} & P. janthenellum & 25.37 & 358.8 & 236.35 & $\mathrm{C}_{15} \mathrm{H}_{24} \mathrm{O}_{2}$ & Hernandulcin & 3.44 \\
\hline & T. viride & 28.17 & 300 & 210.4 & $\mathrm{C}_{15}^{13} \mathrm{H}_{30}$ & 1-Pentadecene & 4.89 \\
\hline \multirow[t]{2}{*}{20} & P. janthenellum & 33.19 & 122 & 223.36 & $\mathrm{C}_{15} \mathrm{H}_{26} \mathrm{O}$ & Nerolidol & 5.42 \\
\hline & T. viride & 33.11 & 41 & 220 & $\mathrm{C}_{15} \mathrm{H}_{24} \mathrm{O}$ & Caryophyllene oxide & 4.52 \\
\hline \multirow[t]{2}{*}{21} & P. janthenellum & 34.16 & 345.5 & 224.33 & $\mathrm{C}_{14} \mathrm{H}_{24} \mathrm{O}_{2}$ & $\begin{array}{l}\text { 5,8-Tetradecadienoic } \\
\text { acid }\end{array}$ & 3.63 \\
\hline & T. viride & 34.26 & 153 & 222 & $\mathrm{C}_{15} \mathrm{H}_{26} \mathrm{O}$ & $\alpha$-Bisabolol & 4.94 \\
\hline \multirow[t]{2}{*}{22} & P. janthenellum & 34.52 & 329 & 238.4 & $\mathrm{C}_{16} \mathrm{H}_{30}{ }^{20} \mathrm{O}$ & Muscone & 2.82 \\
\hline & T. viride & 35.12 & 161 & 222 & $\mathrm{C}_{15} \mathrm{H}_{26} \mathrm{O}$ & Guaiol & 2.32 \\
\hline 23 & P. janthenellum & 35.46 & 211 & 240.42 & $\mathrm{C}_{16} \mathrm{H}_{32}{ }^{20} \mathrm{O}$ & Hexadecanal & 3.12 \\
\hline
\end{tabular}




\begin{tabular}{|c|c|c|c|c|c|c|c|}
\hline & T. viride & 36.16 & 81 & 222 & $\mathrm{C}_{15} \mathrm{H}_{26} \mathrm{O}$ & 6-Epi-shyobunol & 2.99 \\
\hline \multirow[t]{2}{*}{24} & P. janthenellum & 35.59 & 129.66 & 268.5 & $\mathrm{C}_{18} \mathrm{H}_{36} \mathrm{O}$ & Cyclooctadecanol & 1.88 \\
\hline & T. viride & 37.26 & 59 & 222 & $\mathrm{C}_{15} \mathrm{H}_{26} \mathrm{O}$ & Elemol & 2.01 \\
\hline \multirow[t]{2}{*}{25} & P. janthenellum & 36.58 & 156 & 296.5 & $\mathrm{C}_{20} \mathrm{H}_{40}{ }^{26} \mathrm{O}$ & Isophytol & 2.31 \\
\hline & T. viride & 38.48 & 119 & 222.36 & $\mathrm{C}_{15} \mathrm{H}_{26} \mathrm{O}$ & $\alpha$-Acorenol & 3.51 \\
\hline \multirow[t]{2}{*}{26} & P. janthenellum & 37.47 & 343 & 340.58 & $\mathrm{C}_{22} \mathrm{H}_{44} \mathrm{O}_{2}$ & Docosanoic acid & 2.47 \\
\hline & T. viride & 39.57 & 43 & 238 & $\mathrm{C}_{15}^{22} \mathrm{H}_{26}^{44} \mathrm{O}_{2}^{2}$ & Cedrane-8,13-diol & 3.45 \\
\hline \multirow[t]{2}{*}{27} & P. janthenellum & 38.54 & 272 & 368.63 & $\mathrm{C}_{24} \mathrm{H}_{48} \mathrm{O}_{2}$ & Lignoceric acid & 3.29 \\
\hline & T. viride & 41.12 & 55 & 254 & $\mathrm{C}_{16} \mathrm{H}_{30} \mathrm{O}_{2}$ & 9-Hexadecenoic acid & 2.89 \\
\hline \multirow[t]{2}{*}{28} & P. janthenellum & 40.41 & 451 & 480.85 & $\mathrm{C}_{32} \mathrm{H}_{64} \mathrm{O}_{2}^{2}$ & Lacceroic acid & 4.07 \\
\hline & T. viride & 45.11 & 41 & 318 & $\mathrm{C}_{21} \mathrm{H}_{34} \mathrm{O}_{2}$ & Methyl arachidonate & 2.67 \\
\hline \multirow[t]{4}{*}{29} & P. janthenellum & 48.48 & 489.9 & 492.9 & $\mathrm{C}_{35} \mathrm{H}_{72} \mathrm{O}^{2}$ & 1-Pentatriacontanol & 1.64 \\
\hline & T. viride & 49.15 & 43 & 536 & $\mathrm{C}_{37}^{35} \mathrm{H}_{76}^{2 .} \mathrm{O}$ & 1-Heptatriacontanol & 2.44 \\
\hline & & \multirow{2}{*}{\multicolumn{4}{|c|}{$\begin{array}{l}\text { Total identified compounds of } P \text {. janthenellum } \\
\text { Total identified compounds of } T \text {. viride }\end{array}$}} & & 79.18 \\
\hline & & & & & & & 84.17 \\
\hline
\end{tabular}

Penicillium janthenellum exhibited $10 \%$ (wt/ wt). HPLC analysis of total protein content of Trichoderma viride showed seven essential amino acids represented by $40.39 \%$ and eight nonessential amino acids represented by $59.61 \%$ (wt/ wt) (Table 5). On the other hand, HPLC analysis of total protein content of Penicillium janthenellum showed eight essential amino acids represented by $41.49 \%$ and eight non-essential amino acids represented by $58.51 \%$ (wt/wt) (Figs 16 and 17). The volatile constituents of Trichoderma viride and Penicillium janthenellum were represented by $0.14 \%$ of fresh mycelia for each strain. GC/ MS analysis identified 29 compounds which represented by $84.17 \%$ and $79.18 \%$ of the total volatile compounds for Trichoderma viride and Penicillium janthenellum respectively (Table 6).

\section{Xylanase applications}

Wheat and rice straw were more efficiently to xylanase hydrolysis but, sugarcane bagasse was the more intensive one. As the incubation period increased, the reducing sugars released increased (Fig. 18). Results in (Table 7) illustrated that no inhibition zones were detected when disks were loaded with $50 \mu \mathrm{g} /$ disc of the extract. While, $100 \mu \mathrm{g} /$ disc concentration showed remarkable inhibition zone against Candida sp. and $E$. coli which represented by $10.93 \mathrm{~mm}$ and $10.16 \mathrm{~mm}$ respectively. This concentration known as minimum inhibition concentration (MIC). The inhibition zone increased as concentration of crude extraction increased. The crude extraction recorded high inhibition zone at $200 \mu \mathrm{g} / \mathrm{disc}$ which represented by $12.67 \mathrm{~mm}$ and $12.17 \mathrm{~mm}$ for Candida sp. and E. coli respectively.

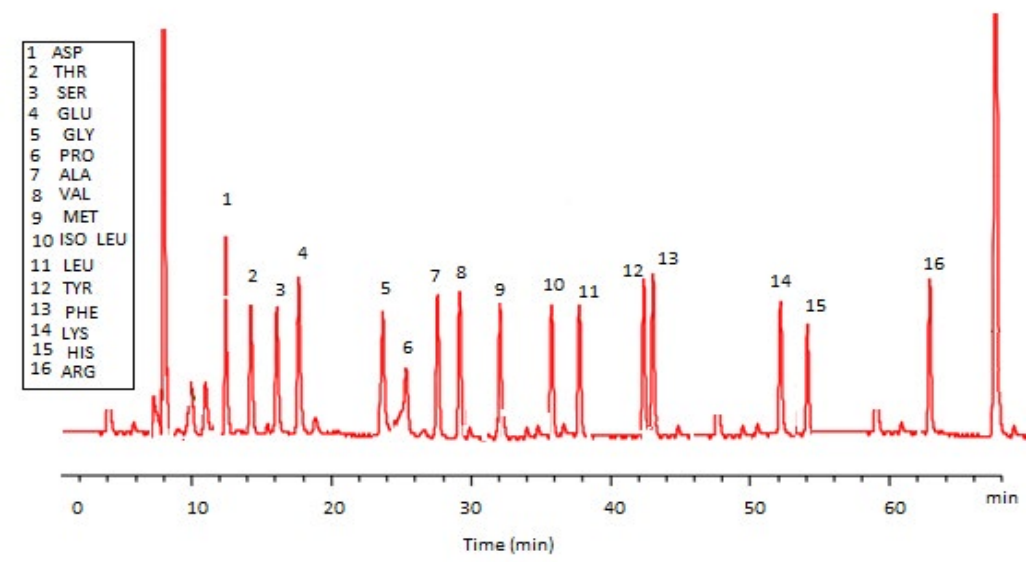

Fig. 16. HPLC analysis of total protein content of Penicillium janthenellum 


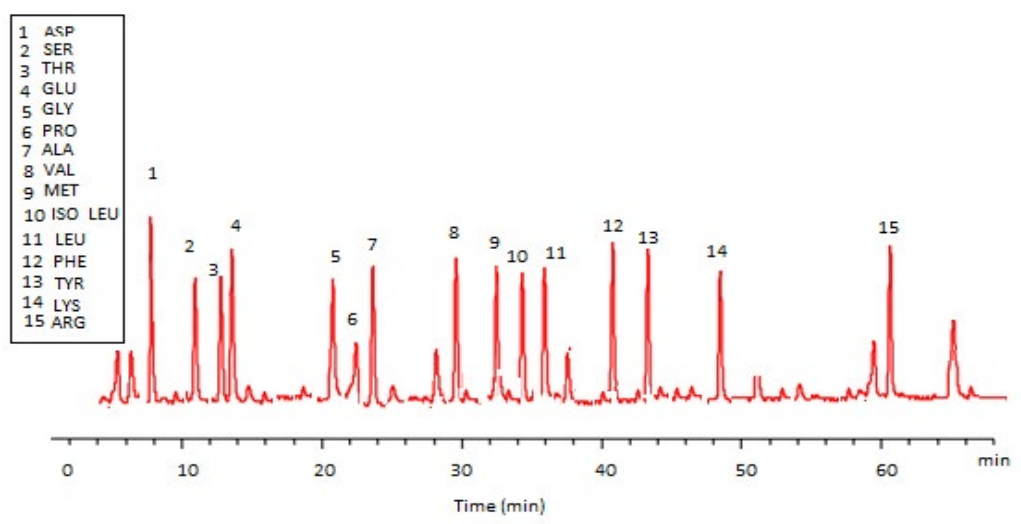

Fig. 17. HPLC analysis of total protein content of Trichoderma viride

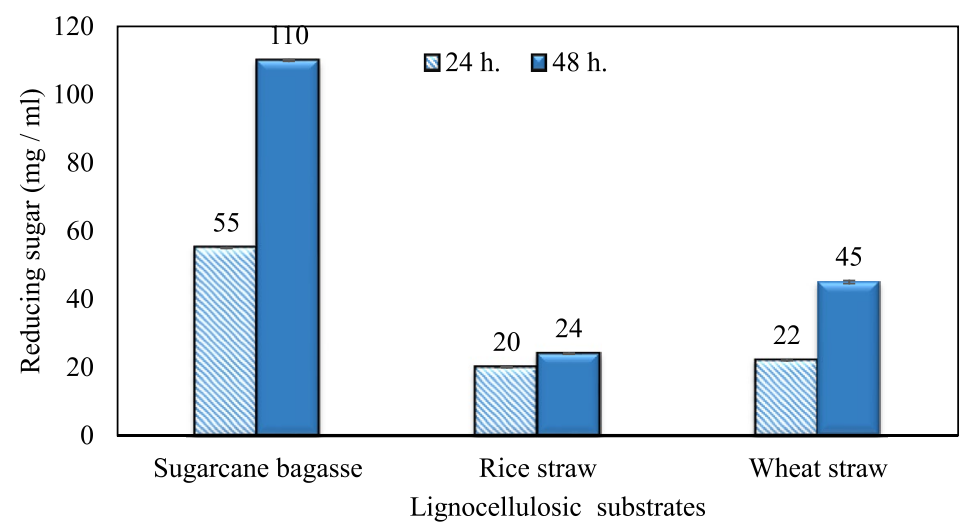

Fig. 18. Treatment of lignocellulosic substrates with purified xylanase

Table 7. Effects of crude extraction of $P$. janthenellum and $T$. viride on fungal and bacterial activities

\begin{tabular}{llllll}
\hline Biological & Tested organisms & \multicolumn{4}{c}{ Diameter of inhibition zone $(\mathrm{mm})$} \\
\cline { 3 - 5 } Activity & & $50 \mu \mathrm{g} / \mathrm{disc}$ & $100 \mu \mathrm{g} / \mathrm{disc}$ & $150 \mu \mathrm{g} / \mathrm{disc}$ & $200 \mu \mathrm{g} / \mathrm{disc}$ \\
\hline Antifungal & Candida sp. & N. D & $10.93 \pm 0.33 \mathrm{a}$ & $11.43 \pm 0.63$ & $12.67 \pm 0.23$ \\
Antibacterial & E. coli & N. D & $10.16 \pm 0.11 \mathrm{a}$ & $11.96 \pm 0.21$ & $12.17 \pm 0.73$ \\
\hline
\end{tabular}

* N. D: no inhibition zone was detected.

* Groups with same letters known as MIC.

\section{DISCUSSION}

In this study, Trichoderma viride was selected to produce xylanase and $\beta$-xylosidase enzymes under solid state fermentation conditions. Agriculture wastes like (sugar beet pulp, (sugar beet pulp + wheat bran), wheat bran, (sugar beet pulp + banana), (sugar beet pulp + broad bean) and broad bean) were used as sources of carbon for xylanase production. It was shown that, the maximum xylanase activity was achieved when sugar beet pulp (SBP) was used as a sole carbon source and yeast extract as a nitrogen source. These results were found to agree with Yardimci and Cekmecelioglu 2018; Ketipally and Ram $2018^{13,38}$ who reported that, xylanase production was increased significantly when arabinose, xylose and cellulose were used as a sole carbon source. Otherwise, they were also reported that, yeast extract, malt extract and peptone with beef extract were the best sources for nitrogen that gave 
higher xylanase activity. In this study, Trichoderma viride showed its maximum xylanase activity on the eighth day of the incubation period. This result was agree with SIPRIYADI et al. $2020^{33}$ who reported that, the maximum activity of xylanase was obtained on the eighth day of incubation. Also, Richhariya et al. $2020^{28}$ reported that, the maximum xylanase production was moderately high when wheat bran was used as a carbon source after 8 days of incubation. Temperature and $\mathrm{pH}$ value are essential factors to find out the maximum xylanase production under solid state fermentation. The optimum temperature and $\mathrm{pH}$ for xylanase production produced by Trichoderma viride achieved at $30^{\circ} \mathrm{C}$ when the $\mathrm{pH}$ was 5.5. These results were found to agree with Richhariya et al. $2020^{28}$ who reported that the optimum xylanase production took place when the $\mathrm{pH}$ was $(6-7)$ at $30^{\circ} \mathrm{C}$ for 8 days of incubation. The enzyme production decreased as $\mathrm{pH}$ and temperature increased. Also, in this study, the maximum xylanase production took place at the inoculum size $1.8 \times 10^{5}$ spores $/ \mathrm{ml}$. This result disagree with Ezeilo et al. $2020^{11}$ who reported that, $1 \times 10^{8}$ spores/g was the optimum inoculum size for xylanase production, while enzyme activity decreased as inoculum size increased. Also, Khanahmadi et al. $2018^{14}$ reported that, the optimum inoculum level for xylanase production was $1 \times 10^{7}$ spores $/ \mathrm{ml}$. Surfactants played an important and positive role in enhancement of enzyme activity. Surfactants induced the enzyme production by increased the penetration of water into the solid substrate and increased the surface area for microbial growth which increased the permeability of the microbial cell membrane and increase the release of proteins into the medium. In this study, the highest xylanase activity was achieved upon addition of Tween 40. While, Tweens 20 and 60 caused slightly increase on the activity as compared to the control. While no effect occurred upon using triton X-100. These results were agree with Bala and Singh $2017^{3}$ who reported that, different surfactants such as Tweens and triton $\mathrm{X}-100$ enhanced production of all the hydrolytic enzymes as compared to other surfactants. Khanahmadi et al. 2018; Nanjundaswamy and Okeke $2020^{14,22}$ reported that, the maximum xylanase production was achieved by the addition of $0.1 \%(\mathrm{w} / \mathrm{v})$ of Tween
20. Gamma-mutagenesis including gamma irradiation has a great importance and advantages as a mutagenic agent. The optimum dose of gamma irradiation used to produce the highest quantity of xylanase was $0.7 \mathrm{kGy}$. Further increase of gamma irradiation doses results in a noticeable decrease of viability of spores. This result disagree with Kostyleva et al. $2018^{16}$ who found that, the most aggressive irradiation dose that gave the highest levels target of the enzyme was $2.5 \mathrm{kGy}$. Xylanase and endoglucanase activities obtained by irradiated $T$. reesei strain were significantly higher than the activities observed in the original strain. On the other hand, mixed culture of recombinant strains can reduce the cost of enzyme production and increase enzyme degrading capability. Trichoderma viride and Penicillium janthenellum mixed cultures used for enhancement of xylanase degrading capability. This result agree with Deshpande et al. $2008^{9}$ who reported that $T$. reesei and $A$. niger mixed cultures used to improve the hydrolysis of xylanase production. Also, Murugan et al. $2015^{20}$ reported that, mixed cultures were produced higher xylanase titers than the monocultures. The results in this study showed that, xylanase was purified by centrifugation, followed by ammonium sulfate method. Kumar et al. $2019^{17}$ were reported that, crude xylanase was precipitated with $60 \%$ of ammonium sulphate, then leave overnight at $4^{\circ} \mathrm{C}$. The obtained results demonstrated that, $\beta$-xylosidase exhibited its maximum activity and stability at $40^{\circ} \mathrm{C}$ when the $\mathrm{pH}$ was 6 by the addition of $\mathrm{Cacl}_{2}$. These results disagree with Ye et al. $2017^{39}$ who reported that, $\beta$-xylosidase exhibited the highest activity at $50^{\circ} \mathrm{C}$ when $\mathrm{pH}$ was 7 by the addition of $\mathrm{Ca}^{+2}$. Also, Wu et al. $2006^{36}$ reported that, monovalent cations had small stimulating effects on the enzymatic activity. Finally, Penicillium janthenellum recorded antifungal effect against Candida sp. and Trichoderma viride recorded antibacterial effect against $E$. coli and these results were agree with Awad et al. $2018^{2}$ who reported that, Trichoderma viride recorded inhibition effect against fungi Rhizoctonia solani, Sclerotome rolfsii and Fusarium solani. Also, the fungal mycelial extract proved antibacterial and antifungal activity against E. coli and Candida albicans respectively at concentration of $100 \mu \mathrm{g} /$ disc. 


\section{CONCLUSION}

In this study, T. viride (RCMB) 017002 and $P$. janthenellum (RCMB) 001033 [1] were obtained from Al Azhar University, The Regional Center for Mycology and Biotechnology, Cairo, Egypt. Strains were selected to grow under solid state fermentation (SSF) conditions for xylanase and $\beta$-xylosidase production. Xylanase produced in this study was characterized by its production using cheaper agricultural wastes. It was found that, the maximum xylanase activity was achieved when the medium was supplemented with sugar beet pulp as a carbone source and yeast extract as nitrogen source when the inoculum size was $1.8 \times 10^{5} \mathrm{spores} / \mathrm{ml}$ for eight days of incubation at $30^{\circ} \mathrm{C}$ by adjusted $\mathrm{pH}$ to 5.5 upon addition of Tween 40 and upon using $0.7 \mathrm{kGy}$ of gamma irradiation does. T. viride and $P$. janthenellum mixed culture used for the enhancement of xylanase production and increased xylanase degrading capability. For xylanase purification, ammonium sulfate method was selected. $\beta$-xylosidase enzyme produced by $T$. viride was found to active and stable at all $\mathrm{pH}$ ranges, it increased gradually until reached its maximum activity and stability at $\mathrm{pH} 6$, then decreased gradually. Also, $\beta$-xylosidase enzyme exhibited its maximum activity and stability at $40^{\circ} \mathrm{C}$. Beyond $40^{\circ} \mathrm{C}$, the activity and stability decreased. Furthermore, $\beta$-xylosidase activity increased by adding $\mathrm{CaCl}_{2}$ as metal ion. T. viride exhibited protein content represented by $12 \%$ (wt/wt) and HPLC analysis showed seven essential amino acids and eight non-essential amino acids represented by $40.39 \%$ and $59.61 \%$ (wt/wt) respectively while, $P$. janthenellum exhibited protein content represented by $10 \%(\mathrm{wt} / \mathrm{wt})$ and HPLC analysis showed eight essential amino acids and eight non-essential amino acids represented by $41.49 \%$ and $58.51 \%(\mathrm{wt} / \mathrm{wt}$ ) respectively. The volatile constituents of $P$. janthenellum and $T$. viride represented by $0.14 \%$ of fresh mycelia. GC/MS analysis identified 29 compounds which represented by 79.18 and $84.17 \%$ of the total volatile compounds for $P$. janthenellum and $T$. viride respectively. Lignocellulosic residues were found to be susceptible for xylanase hydrolysis. T. viride and Penicillium janthenellum played an important role in the human health by producing several important secondary metabolites which could be used as potential antimicrobial drugs.

\section{ACKNOWLEDGMENTS}

Strains that selected in this study were obtained from Al Azhar University, The Regional Center for Mycology and Biotechnology, Cairo, Egypt. Thanks to Botany Department, Faculty of Science, Al-Azhar University, Cairo, Egypt

\section{CONFLICT OF INTEREST}

The authors declare that there is no conflict of interest.

\section{AUTHORS' CONTRIBUTION}

All authors listed have made a substantial, direct and intellectual contribution to the work, and approved it for publication.

\section{FUNDING}

None.

\section{DATA AVAILABILITY}

All data included in this study were presented in the form of tables and Figures.

\section{ETHICS STATEMENT}

The protocol of this study was approved by the Faculty of Science, Al-Azhar University, Cairo, Egypt (2017).

\section{REFERENCES}

1. Ahmed I, Zia MA, Hussain MA, Akram Z, Naveed MT, Nowrouzi A. 'Bioprocessing of Citrus Waste Peel for Induced Pectinase Production by Aspergillus Niger; Its Purification and Characterization'. Journal of Radiation Research and Applied Sciences. 2016;9:148-154. doi: 10.1016/j.jrras.2015.11.003

2. Awad NE, Kassem HA, Hamed MA, et al. 'Isolation and Characterization of the Bioactive Metabolites from the Soil Derived Fungus Trichoderma Viride'. Mycology. 2018;9:70-80. doi: 10.1080/21501203.2017.1423126

3. Bala A, Singh B. 'Concomitant Production of Cellulase and Xylanase by Thermophilic Mould Sporotrichum Thermophile in Solid State Fermentation and Their Applicability in Bread Making'. World J Microbiol Biotechnol. 2017; 33:109. doi: 10.1007/s11274-0172278-6

4. Bellomonte G, Costantini A, Giammarioli S. 'Comparison of Modified Automatic Dumas Method and the Traditional Kjeldahl Method for Nitrogen Determination in Infant Food'. Journal of the Association of Official Analytical Chemists. 1987;70:227-229. doi: 10.1093/jaoac/70.2.227

5. Bhardwaj V. Degrassi G, Bhardwaj RK. 'Bioconversion of Cellulosic Materials by the Action of Microbial Cellulases'. 2017.

6. Biely P, Singh S, Puchart V. 'Towards Enzymatic 
Breakdown of Complex Plant Xylan Structures: State of the Art'. Biotechnol Adv. 2016;34:1260-1274. doi: 10.1016/j.biotechadv.2016.09.001

7. Bills GF, Gloer JB. 'Biologically Active Secondary Metabolites from the Fungi'. The Fungal Kingdom. 2017:1087-1119. doi: 10.1128/9781555819583.ch54

8. Pereira JC, Marques NP, Rodrigues A, et al. 'Thermophilic Fungi as New Sources for Production of Cellulases and Xylanases with Potential Use in Sugarcane Bagasse Saccharification'. J Appl Microbiol. 2015;118:928-939. doi: 10.1111/jam.12757

9. Deshpande SK, Bhotmange MG. Chakrabarti T, Shastri PN. 'Production of Cellulase and Xylanase by Trichoderma Reesei (Qm 9414 Mutant), Aspergillus Niger and Mixed Culture by Solid State Fermentation (Ssf) of Water Hyacinth (Eichhornia Crassipes)'. 2008.

10. Devi R, Kaur T, Guleria G, et al. 'Fungal Secondary Metabolites and Their Biotechnological Applications for Human Health'. New and Future Developments in Microbial Biotechnology and Bioengineering. Elsevier. 2020:147-161. doi: 10.1016/B978-0-12-8205280.00010-7

11. Ezeilo UR, Wahab RA, Mahat NA. 'Optimization Studies on Cellulase and Xylanase Production by Rhizopus Oryzae Uc2 Using Raw Oil Palm Frond Leaves as Substrate under Solid State Fermentation'. Renewable Energy. 2020;156:1301-1312. doi: 10.1016/j.renene.2019.11.149

12. Giovannoni M, Gramegna G, Benedetti M, Mattei B. 'Industrial Use of Cell Wall Degrading Enzymes: The Fine Line between Production Strategy and Economic Feasibility'. Frontiers in Bioengineering and Biotechnology. 2020;8:356. doi: 10.3389/ fbioe.2020.00356

13. Ketipally R, Ram MR. 'Optimization of Pectinase Production by Aspergillus Oryzae $\operatorname{Rr} 103$ '. Current Agriculture Research Journal. 2018;6:37-44. doi: 10.12944/CARJ.6.1.05

14. Khanahmadi M, Arezi I, Amiri M-S, Miranzadeh M. 'Bioprocessing of Agro-Industrial Residues for Optimization of Xylanase Production by Solid-State Fermentation in Flask and Tray Bioreactor'. Biocatalysis and Agricultural Biotechnology. 2018;13:272-282. doi: 10.1016/j.bcab.2018.01.005

15. Khattab TA, Abdelrahman MS, Rehan M. 'Textile Dyeing Industry: Environmental Impacts and Remediation'. Environmental Science and Pollution Research. 2020:116.

16. Kostyleva EV, Tsurikova NV, Sereda AS, et al. 'Enhancement of Activity of Carbohydrases with EndoDepolymerase Action in Trichoderma Reesei Using Mutagenesis'. Microbiology. 2018;87:652-661. doi: 10.1134/S0026261718050120

17. Kumar SS, Abrar A, Jai G, Raj MD. 'Partial Purification and Characterization of Xylan Degrading Alkaline Xylanase from Bacillus Subtilis'. Research Journal of Chemistry and Environment. 2019;23(9).

18. Lunin V, Wang H-T, Bharadwaj V, et al. 'Molecular Mechanism of Polysaccharide Acetylation by the Arabidopsis Xylan O-Acetyltransferase Xoat1'. The Plant Cell. 2020.

19. Miller GL. 'Use of Dinitrosalicylic Acid Reagent for Determination of Reducing Sugar'. Analytical Chemistry. 1959;31:426-428. doi: 10.1021/ ac60147a030

20. Murugan P, Jampala P, Ramanujam S, Uppuluri KB. 'Production of Xylanase from a Mixed Culture System of Acetobacter Xylinum and Cellulomonas Uda in Submerged Fermentation'. Biosci Biotechnol Res Asia. 2015;12:1615-1622. doi: 10.13005/bbra/1823

21. Naik SN, Goud VV, Rout PK, Dalai AK. 'Production of First and Second Generation Biofuels: A Comprehensive Review'. Renewable and Sustainable Energy Reviews. 2010;14:578-597. doi: 10.1016/j.rser.2009.10.003

22. Nanjundaswamy A, Okeke BC. 'Comprehensive Optimization of Culture Conditions for Production of Biomass-Hydrolyzing Enzymes of Trichoderma Sg2 in Submerged and Solid-State Fermentation'. Appl Biochem Biotechnol. 2020:191:444-462. doi: 10.1007/ s12010-020-03258-1

23. Pandey P, Kiran UV. 'Degradation of Paints and Its Microbial Effect on Health and Environment'. Journal of Critical Reviews. 2020;7:4879-4884.

24. Pandiyan K, Singh A, Singh S, Saxena AK, Nain L. 'Technological Interventions for Utilization of Crop Residues and Weedy Biomass for Second Generation Bio-Ethanol Production'. Renewable Energy. 2019;132:723-741. doi: 10.1016/j.renene.2018.08.049

25. Uday USP, Bandyopadhyay TK, Bhunia B. 'Rapid Development of Xylanase Assay Conditions Using Taguchi Methodology'. Bioengineered. 2016;7:424431. doi: 10.1080/21655979.2016.1180486

26. Priyanka SB. 'Isolation, Purification and Characterization of Pectinase Enzyme from Streptomyces Thermocarboxydus'. Journal of Biotechnology \& Bioresearch. 2019;1(5). doi: 10.31031/JBB.2019.01.000523

27. Ravindran R, Hassan SS, Williams GA, Jaiswal AK. 'A Review on Bioconversion of Agro-Industrial Wastes to Industrially Important Enzymes'. Bioengineering. 2018:5:93. doi: 10.3390/bioengineering5040093

28. Richhariya J, Sharma TK, Dassani S. 'Production and Optimization of Enzyme Xylanase by Aspergillus Flavus Using Agricultural Waste Residues'. Journal of Applied Biology \& Biotechnology. 2020;8:82-89. doi: 10.7324/ JABB.2020.80413

29. Saharan R, Sharma KP. 'Production, Purification and Characterization of Pectin Lyase from Bacillus Subtilis Isolated from Moong Beans Leaves (Vigna Radiata)'. Biocatalysis and Agricultural Biotechnology. 2019;21:101306. doi: 10.1016/j.bcab.2019.101306

30. Sarkar N, Ghosh SK, Bannerjee S, Aikat K. 'Bioethanol Production from Agricultural Wastes: An Overview'. Renewable Energy. 2012;37:19-27. doi: 10.1016/j. renene.2011.06.045

31. Shrestha S, Kognou ALM, Zhang J, Qin W. 'Different Facets of Lignocellulosic Biomass Including Pectin and Its Perspectives'. Waste and Biomass Valorization. 2020:1-19. doi: 10.1007/s12649-020-01305-w

32. Singh RL. 'Introduction to Environmental Biotechnology', in Principles and Applications of Environmental Biotechnology for a Sustainable Future Springer. 2017:1-12. doi: 10.1007/978-981-10-18664_1 
33. Sipriyadi S, Wahyudi AT, Suhartono MT, Meryandini A. 'Optimization of Xylanase Production by Streptomyces Costaricanus 45i-3 Using Various Substrates through Submerged Fermentation'. Microbiology Indonesia. 2020;14:5. doi: 10.5454/mi.14.1.5

34. Thapa S, Indrawan N, Bhoi PR. 'An Overview on Fuel Properties and Prospects of Jatropha Biodiesel as Fuel for Engines', Environmental Technology \& Innovation. 2018;9:210-219. doi: 10.1016/j.eti.2017.12.003

35. A Book Review| Extremophilic Enzymatic Processing of Lignocellulosic Feedstocks to Bioenergy, K. Sanirajesh, R. Navanietha Krishnaraj (Eds.), Springer. 2017:308. Ebook Isbn: 978-3-319-54684-1. doi: 10.1007/978-3319-54684-1

36. Wu S, Liu B, Zhang X. 'Characterization of a Recombinant Thermostable Xylanase from Deep-Sea Thermophilic
Geobacillus Sp. Mt-1 in East Pacific', Appl Microbiol Biotechnol. 2006;72:1210-1216. doi: 10.1007/s00253006-0416-4

37. Yadav AN, Singh S, Mishra S, Gupta A. 'Recent Advancement in White Biotechnology through Fungi'. Elsiver. 2019.

38. Yardimci GO, Cekmecelioglu D. 'Assessment and Optimization of Xylanase Production Using Co-Cultures of Bacillus Subtilis and Kluyveromyces Marxianus'. 3 Biotech. 2018;8:290. doi: 10.1007/s13205-018-1315-y

39. Ye Y, Li X, Zhao J. 'Production and Characteristics of a Novel Xylose-and Alkali-Tolerant Gh 43 B-Xylosidase from Penicillium Oxalicum for Promoting Hemicellulose Degradation'. Sci Rep. 2017;7:11600. doi: 10.1038/ s41598-017-11573-7 